\title{
MAKNA SIMBOL TRADISI BURAK DALAM KOMUNIKASI RITUAL SUKU BUGIS DI KOTA BENGKULU
}

\author{
Rini Fitria \& Rohmad Fadli
}

\begin{abstract}
Abstrak
Tradisi Burak yang dilaksanakan suku Bugis di kota Bengkulu, sebagai rasa syukur kepada sang pencipta karena telah diberikan anugerah baik berupa pernikahan, kelahiran ataupun perayaan hari besar Islam. Makna simbol tradisi Burak dalam komunikasi ritual suku Bugis di kota Bengkulu yang terkandung dalam setiap simbol Burak yaitu; 1) Batang pisang bermakna menegakkan agama Islam, 2) Batang bambu, bermakna aqidah yang kuat dan lurus untuk menyembah Allah dan mencontoh sikap Rasul, 3) Telur yang terdiri dari tiga bagian yaitu: cangkang telur, putih telur dan kuning telur (inti) bermakna fisik, Jiwa dan qolbu, 4) Kertas berwarna di bentuk beraneka bunga bermakna rahmat bagi seluruh alam.
\end{abstract}

Kata kunci: tradisi, burak, simbol, ritual, komunikasi

\section{Pendahuluan}

Kebudayaan merupakan sebuah identitas dari setiap kelompok manusia. Dimana kelompok manusia memiliki ciri khas kebudayaannya masing-masing. Kebudayaan timbul dari kebiasaan yang dilakukan oleh dan akan menjadi sebuah tradisi apabila kebudaayaan tersebut telah ada serta dilestarikan oleh generasi berikutnya. Dengan kata lain kebudayaan tersebut merupakan turunan dari kebiasaan yang dilakukan oleh nenek moyang terdahulu dan sekarang masih dilaksanakan kebiasaan-kebiasaan tersebut.

Salah satu media yang digunakan dalam melestarikan sebuah kebudayaan yaitu komunikasi. Salah satu fungsi komunikasi dalam sistem sosial adalah memajukan kebudayaan dengan menyebarkan hasil kebudayaan dan seni dengan maksud melestarikan warisan masa lalu (Rini Fitria, 2005: 2). Setiap kebiasaan yang dilakukan oleh manusia tidak terlepas dari makna atau nilai-nilai dalam sebuah simbol yang ada pada sebuah kebudayaan. Dari setiap makna tersebut sangat mempengaruhi tingkah laku dari pemiliki kebiasaan itu.

Diberbagai belahan dunia manapun sudah pasti memiliki kebiasaanya masingmasing. Indonesia lebih dari ratusan kebudayaan berkembang diseluruh pelosok nusantara mulai dari Sabang hingga Merauke. Indonesia yang terkenal dengan keberagaman kebudayaan, adat 
istiadat serta bermacam-macam suku yang mendiami setiap pulau-pulau yang ada.

Provinsi yang berada di daerah pesisir yaitu Bengkulu, merupakan provinsi yang memiliki banyak sekali suku dan juga kebudayaan yang berkembang di dalamnya. Selain dari suku asli yang mendiami provinsi Bengkulu, terdapat suku-suku lain dari berbagai daerah di Nusantara.

Salah satu suku yang ada di Indonesia yakni suku Bugis, merupakan suku yang berada di pesisir provinsi Sulawesi Selatan. Kebanyakan mata pencaharian masyrakat suku Bugis adalah nelayan. Seiring perkembangan zaman banyak masyarakat suku Bugis transmigrasi ke provinsi Bengkulu yang memiliki pantai terpanjang di Indonesia.

Suku Bugis masih melaksanakan adat kebiasaan walaupun tidak lagi mendiami daerah asalnya. Seperti pada perayaan hari raya Idul Fitri masyarakat suku Bugis tidak pernah ketinggal menyediakan makanan khas yaitu Tumbuk, Burasan dan macam-macam makanan lain yang disajikan untuk para tamu yang datang bersilahturahmi.

Tradisi lain yang hingga sekarang masih dilaksanakan suku Bugis yaitu tradisi Burak. Burak merupakan sebuah tradisi yang dilakukan pada saat peringatan Maulid Nabi Muhammad SAW, doa kelahiran anak, serta tradisi yang dilakukan pada saat khatam al-Qur'an bagi masyarakat suku Bugis yang hendak melangsungkan pernikahan.

Tradisi Burak ini memiliki berbagai simbol dalam pelaksanaan ritualnya, dan setiap simbol tersebut memiliki makna tersendiri dalam komunikasi ritual dan terjaga dari generasi ke generasi.

Penelitian ini akan membahas makna simbol tradisi Burak dalam komunikasi ritual masyarakat suku Bugis di kota Bengkulu.

\section{Metode Penelitian}

a. Pendekatan dan Jenis Penelitian

Penelitian ini menggunakan pendekatan kualitatif deskriptif dengan jenis penelitian lapangan (field research). Bogdan dan Taylor menjelaskan seperti yang dikutip oleh Moleong, metode kualitatif interpretative adalah sebagai prosedur penelitian yang menghasilkan data secara deskriptif berupa kata-kata tertulis atau lisan dari orang-orang dan perilaku yang dapat diamati (Moleong, 2009: 4).

b. Informan Peneliti

Informan adalah orang yang memberikan informasi. Informan dapat dikatakan sama dengan responden, apabila pemberian keterangannya karena dipancing oleh pihak peneliti (Saifudin dan Arikunto, 2009: 145). Pemilihan informan penelitian ini diambil dengan teknik Proposive sampling.

Proposive sampling yaitu 
menentukan informan dengan pertimbangan tertentu yang dapat memberikan data secara maksimal. Proposive sampling digunakan peneliti jika peneliti mempunyai pertimbanganpertimbangan tertentu dalam pengambilan atau penentuan sampel (Sugiyono, 2009: 218). Informan dalam penelitian ini adala suku Bugis yang berada di kota Bengkulu.

\section{c. Sumber Data dan Lokasi Penelitian}

Dalam penelitian ini terdapat data utama (primer) dan data pendukung (sekunder).

\section{Data Primer}

Data primer adalah data yang langsung dikumpulkan oleh peneliti dari sumber pertanyaan (Nasution, 2003: 39). Sumber data ini adalah tokoh adat dan masyarakat suku Bugis di kota Bengkulu.

\section{Data Sekunder}

Nasutian menjelaskan data sekunder adalah data yang sudah tersusun dan sudah dijadikan dalam bentuk dokumen-dokumen (Nasuition, 2003: 40). Adapun sumber data sekunder di sini adalah buku-buku, artikel, dokumentasi yang berkaitan dengan makna dan simbol tradisi Burak.

\section{d. Teknik Pengumpulan Data}

\section{Observasi Partisipan}

Observasi partisipan diartikan sebagai pengamatan dan pencatatan secara sistematik terhadap gejala yang tampak pada objek penelitian.
Pengamatan dan pencatatan yang dilakukan terhadap objek di tempat terjadi atau berlangsungnya peristiwa, sehingga observasi berada bersama objek yang diselidiki, disebut observasi berlangsung (Margono S. 2009: 158-159).

Metode observasi adalah cara menghimpun bahan-bahan yang digunakan dengan mengadakan pengamatan fenomena-fenomena yang dijadikan pengamatan. Peneliti melakukan pengamatan dengan cara melihat, mengamati dan berinteraksi dengan masyarakat suku Bugis. observasi partisipan ini akan menggali tentang makna simbol dari tradisi burak pada masyarakat suku Bugis yang berada di kota Bengkulu.

2. Wawancara Mendalam (in depth interview)

Menurut Arikunto, wawancara (interview) merupakan proses tanya jawab lisan dalam dua orang atau lebih berhadapan secara fisik yang satu dapat melihat muka yang lain dan mendengar telingan sendiri suaranya (Arikunto, 2012: 145).

Menurut Nasution, wawancara (interview) adalah suatu bentuk komunikasi verbal, semacam percakapan yang bertujuan memperoleh informasi (Nasution, 2008:113). Secara umum wawancara adalah cara penghimpunan bahan-bahan keterangan yang dilaksanakan dengan melakukan dan dengan arahan serta dengan tujuan yang 
telah ditentukan peneliti.

\section{Dokumentasi}

Menurut Arikunto, metode dokumentasi yaitu mencari data mengenai hal-hal atau variabel yang berupa catatan, transkrip, buku, surat kabar, majalah, prasasti, agenda dan sebagainya (Arikunto, 2012: 148). Dokumentasi dalam penelitian ini diperlukan untuk memperkuat data-data yang diperoleh dari lapangan yaitu dengan cara mengumpulkan data yang berupa catatan tertulis berupa dokumentasi.

\section{e. Teknik Analisis Data}

Menurut Pavon, seperti yang dikutip Moleong dalam bukunya, teknik analisis data dalah proses kategori urutan data, mengorganisasikan kedalam suatu pola, kategori urutan data, mengorganisasikan kedalam suatu pola dan suatu uraian dasar (Moleong, 2009: 130).

Analisis data digunakan awal penelitian sampai hingga akhir pengumpulan data yang bersifat terbuka dan induktif, sehingga tidak menutup kemungkinan akan terjadi reduksi data, perbaikan dan verifikasi data yang diperoleh. Hal ini dimaksudkan untuk lebih mempermudah pemahaman dan kejelasan.

\section{Pengumpulan Data}

Pengumpulan data merupakan hasil dari data informasi yang diperoleh dari pengumpulan data baik menggunakan metode wawancara mendalam, observasi partisipan dan dokumentasi. Data yang terkumpul masih berupa data mentah yang belum diolah, sehingga masih perlu mengkoding data yang penting dan tidak, disesuaikan dengan keperluan penelitian. 2. Verifikasi Data

Verifikasi adalah pembuktian, yaitu proses mencari arti benda-benda, mencatat keteraturan, pola-pola dan penjelasan, kemudian data disajikan dan disimpulkan dari data wawancara, observasi dan diverifikasi sesuai dengan data yang diperlukan.

\section{Reduksi Data}

Reduksi data dimaksudkan untuk memperoleh data yang lebih fokus dan tajam, karena data yang menumpuk belum dapat memberi gambaran yang jelas. Reduksi data merupakan penyederhanaan yang diperoleh dari catatan lapangan sebagai upaya untuk mengorganisasikan data dan memudahkan penarikan kesimpulan dari hasil pengumpulan data melalui wawancara, observasi direduksi sesuai dengan rumusan masalah.

\section{Penyajian Data}

Data yang dihasilkan melalui proses reduksi data akan langsung disajikan sebagai kumpulan informasi terusan yang memberikan kemungkinan adanya penarikan kesimpulan dan pengambilan tindakan. Peneliti membuat deskripsi dan pembahasan hasil penelitian.

5. Kesimpulan

Dari hasil pengumpulan data 
kemudian diverifikasi, direduksi dan disajikan dan pada tahap akhir akan disimpulkan sesuai dengan pertanyaan penelitian.

\section{f. Teknik Validitas Data}

Menurut Nasution, validitas data merupakan faktor yang penting dalam sebuah penelitian karena sebelum data dianalisis terlebih dahulu harus mengalami pemeriksaan. Validitas membuktikan hasil yang diamati sudah sesuai dengan kenyataan dan memang sesuai yang sebenarnya atau kejadian (Nasution, 2003: 105).

Teknik pengujian validitas data yang digunakan dalam penelitian ini adalah dengan menggunkaan triangulasi. Menurut moleong, triangulasi adalah teknik pemeriksaan keabsahan dengan memanfaatkan suatu yang lain dari data tersebut sebagai bahan pembanding atau pengecekan dari data itu sendiri (Lexy $\mathrm{J}$ Moleong, 2009: 330). Teriangulasi dengan sumber berarti membandingkan dengan mengecek balik derajat kepercayaan suatu informasi yang diperoleh melalui waktu dan alat yang berbeda dalam penelitian kualitatif. Hal ini menurut Moleong dapat dicapai dengan jalan:

1. Membandingkan data hasil pengamatan dan data hasil wawancara.

2. Membandingkan yang dikatakan orang di depan umum dengan apa yang dikatakannya secara pribadi.

3. Membandingkan dengan apa yang dikatakan orang-orang dengan situasi penelitian dengan apa yang dikatakan sepanjang waktu.

4. Membandingkan hasil wawan-cara dengan isi dokumen yang berkaitan.

\section{HASIL DAN PEMBAHASAN}

\section{A. Pengertian Simbol}

Simbol adalah suatu rangsangan mengandung makna dan nilai yang dipelajari bagi manusia dan respon manusia terhadap simbol (Dedy Mulyana, 2001: 77). Pierce mengemukakan seperti yang dikutip oleh Sobur dalam bukunya bahwa simbol diartikan sebagai tanda yang mengacu pada obje tertentu di luar tanda itu sendiri. Hubungan antara simbol sebagai penanda dengan sesuatu yang ditandakan (petanda) sifatnya konvensional. Berdasarkan konvensi itu pula masyarakat yang menggunakan menafsirkan cirri hubungan antara simbol dengan objek yang diacu dan menafsirkan maknanya (Alex Sobur, 2003: 156).

Dalam bahasa komunikasi, simbol seringkali diistilahkan sebagai lambang, yaitu sesuatu yang meliputi kata-kata (pesan verbal), perilaku nonverbal dan objek yang maknanya disepakati bersama. Ogden dan Richards (dalam Aminuddin, 1997: 205-207) menyatakan simbol memiliki hubungan asosiatif dengan pikiran atau referensi, simbol dan dunia acuan.

Manusia sebagai pelaku komunikasi, terlihat sangat unik karena 
manusia tersebut dapat memanipulasi simbol-simbol berdasarkan kesadarannya. Sebagaimana Mead menekankan pentingnya komunikasi, khusunya melalui mekanisme isyarat vocal (bahasa), meskipun teorinya bersifat umum. Isyarat vocal tersebutlah yang potensial menjadi seperangkat simbol yang membentuk bahasa. Shibutani mengatakan makna pertama-tama merupakan property perilaku dan kedua merupakan property objek (Mulyana, 2001: 77). Sehingga, semua objek simbolik menyarankan suatu rencana tindakan (plan of action) dan bahwa alasan untuk berperilaku dengan suatu cara tertentu terhadap suatu objek antara lain diisyaratkan oleh objek tersebut.

Menurut Pateda, lambang atau simbol yang ditimbulkan oleh manusia dapat dibedakan atas simbol yang bersifat verbal dan nonverbal (Pateda, 2001: 48). Simbol verbal merupakan simbol-simbol yang digunakan sebagai alat komunikasi yang dihasilkan oleh alat bicara. Sedangkan simbol nonverbal dapat berupa simbol menggunakan anggota badan, lalu diikuti dengan lambing, suara serta benda-benda yang bermakna kultural dan ritual.

\section{B. Jenis Simbol}

Bahtiar (dalam Triyono, 1992: 19) menjelaskan berdasarkan sifatnya simbol memiliki empat jenis, yakni:

\section{b.1.1. Simbol Konstitutif}

Simbol konstitutif yang berbentuk kepercayaan-kepercayaan telah dikenal oleh nenek moyang kita sejak zaman prasejarah, masyarakat prasejarah dengan pola piker yang masih sangat sederhana (primitive) kehidupannya masih sangat tergantung pada alam. Alam adalah sesuatu yang misteri bagi mereka. Kehidupan mereka penuh dengan mitos untuk menjinakan alam yang terkandang membawa bencana bagi kehidupan mereka. Dengan kepercayaan Animisme dan Dinamismenya mereka menggunakan simbol-simbol sebagai sarana persembahan kepada dewa-dewa yang menguasai alam.

Kehidupan simbolisme dalam bidang kepercayaan dan agama ini berlanjut terus sepanjang peradaban manusia di muka bumi ini. Simbol-simbol tersebut nampak pada cara peribadatan mereka dan pada sarana peribadatan meraka (Yudoseputro, 1991: 35). Dalam agama Islam dapat kita jumpai simbolsimbol, seeprti ketika adanya suatu permohonan yang diharapkan untuk dikabulkan, biasanya dengan menengadahkan tangan dan menundukkan kepala sebagai tanda memohon, untuk diterima do'a dan menundukkan kepala tanda kekhusukan seseorang dalam berdo'a.

\section{b.1.2. Simbol Kognitif \\ Simbol-simbol kognitif adalah simbol-simbol yang digunakan di dalam}


ilmu pengetahuan.

Menurut Langer dalam Tjetjep Rohedi mengatakan simbol ilmu pengetahuan adalah simbol diskursif (discursive symbol) atau nalar suatu simbol dengan menggunakan nama lagika-logika modern yang menganalisa pernyataan-pernyataan. Pernyataan tersebut dapat berupa makna dari suatu "nama unsure" yang dipergunakan dalam ilmu pengetahuan. Simbol ini akhirnya terungkap paling jelas dalam bahasa yang memimiliki konstruksi secara konsekuen (Rohedi, 1983: 47). Makna yang terkandung dalam simbol ilmu pengetahuan adalah makna tunggal, bersifat rasional, bersumber pada pada fakta-fakta obyektif karena itu pula analisis adalah analisis ilmu pengetahuan.

\section{b.1.3. Simbol Evaluatif}

Simbol evaluatif atau penelian moral yang membentuk nilai-nilai atau aturan-aturan dalam kehidupan manusia. Jenis simbol ini umunya ditentukan didalam masyarakat tradisional yang tengah memegang adat istiadat yang diwariskan secara turun temurun. Simbol evaluatif diperagakan sejak bayi manusia masih dalam kandungan, saat dilahirkan, menikah sampai meninggal. Bahkan beberapa suku bangsa melakukan upacara kematian sampai beberapa waktu setelah jasad di makamkan.

\section{b.1.4. Simbol Ekspresif}

Simbol ekspresif atau pengungkapan perasaan adalah simbol yang terdapat di dalam karya seni, simbol ekspresif menurut Langger adalah simbol yang presentasional atau penghadir. Pemahaman terhadap simbol ekspresif tidak tergantung pada hukum yang mengatur perhubungan unsure-unsurnya melainkan pada intuisi langsung. Simbol ini bukan sebagai kontruksi yang bisa dipisahkan unsure-unsurnya, melainkan satu kesatuan yang menyatu (Rohedi, 1983: 47).

Seni merupakan sebagai hasil dari ekspresif manusia sekaligus merupakan media komunikasi antara seniman dengan publik sekitarnya. Pada seni komunikasi tidak berbentuk yang berkutub dua seperti dalam komunikasi biasanya yakni komunikasi dua orang, ekspresif yang dilakukan mengarah keluar, tetapi tidak dengan tujuan tertentu. Keistimewaan ekspresif ini adalah memperhalus sari komunikasi menjadi suatu persentuhan rasa yang kental, yakni dengan menyalurkan kesan dan pengalaman seniman kepada public. Dengan kehalusan dan cirri simboliknya yang khas itu, seni mengajak publik untuk mengalami nilai-nilai keindahan (Rohedi, 1983: 49).

\section{Fungsi Simbol}

Tubbs dan Moss mendefinisikan simbol sebagai sesuatu yang dipergunakan untuk atau dipandang 
sebagai wakil sesuatu yang lainnya (Mulyana, 2001: 72). Misalkan bunga Rafflesia dan batik basurek menandakan ciri khas dari provinsi Bengkulu, dimana gambar tersebut menandakan bahwa manusia dapat menggali sesuatu dengan tanda.

Manusia sebagai makhluk simbolik, karena kehidupan manusia tidak pernah terlepas dari simbol-simbol dan simbol ini akan mengandung berbagai makna tergantung pada persepsi setiap orang, sebab manusia tidak bertindak terhadap sesuatu melainkan berdasarkan makna yang dapat diinterpretasikannya. Dengan demikian fungsi dari simbol terletak pada seseorang yang bersangkutan, seperti bacaan mantra pada suatu ritual misalnya bagi orang yang meyakini bahwa apa yang dibaca oleh dukun sangat ampuh untuk mempengaruhi orang lain.

Fungsi simbol yang dipergunakan dalam kehidupan manusia, memungkinkan bagi manusia untuk dapat berpikir, berhungan dengan orang lain dan membentuk serta menafsirkan makna apa yang ditampilkan oleh alam di jagat raya. Simbol tidaklah berdiri atau ada dengan sendirinya, simbol diciptakan dengan mempunyai tujuan yang hendak di informasikan kepada orang yang melihat simbol itu sendiri.

Hayakawa dalam Mulyana mengungkapkan bahwa kebutuhan dasar yang memang hanya da pada manusia yakni kebutuhan akan simbol-simbol (Mulyana, 2001: 6). Fungsi pembentukan simbol ini adalah suatu kegiatan dasar manusia seperti makna akan gerak. Hal ini merupakan proses fundamental dari fikiran dan berlangsung setiap waktu. Tidak semua makhluk di dunia ini dapat memaknai simbolo, karena simbol itu sendiri merupakan isyarat yang hanya dapat dipahami dengan suatu kemampuan dan kemampuan ini hanya dimiliki oleh manusia.

\section{Pengertian Tradisi}

Dalam bahasa Inggris tradisi yakni tradition, bahasa Prancis yakni tradicio yang keduanya memiliki arti diteruskan (dalam Alex Sobur, 2014: 820) atau dapat pula diartikan sebagai kebiasaan. Secara sederhana tradisi adalah sesuatau yang telah dilakukan sejak lama dan menjadi bagian dari kehidupan suatu kelompok masyarakat, biasanya dari suatu Negara, kebudayaan, waktu atau agama yang sama. Dimana hal yang paling mendasar dari sebuah tradisi yakni informasi yang diteruskan atau kebiasaan yang dilakukan dari generasi ke generasi baik secara tersirat ataupun tersurat, tanpa adanya penerusan kebiasaan tersebut segala sesuatu akan hilang atau punah.

Tradisi termasuk kedalam bidang kehidupan manusia yang dapat dikatakan sebagai sesuatu yang penting. Contohnya seperti pertalian atau hubungan keluarga, agama, pemerintahan, serta kultur kelas 
atas seperti seni dan sastra (Sobur, 2014: 821). Dalam penggunakan kata tradisi atau kebiasaan kita sering sekali menggunakan kata atau istilah adat istiadat, dimana keseluruhan istilah tersebut memiliki arti kebiasaan yang telah diwariskan oleh nenek moyang atau para leluhur sebelumnya.

Tradisi atau kebiasaan ini lebih dikenal sebagai keyakinan dengan istilah animism dan dinamisme. Animism berarti percaya kepada roh-roh halus atau roh leluhur yang ritualnya terekspresikan dalam persembahan tertentu di tempattepat yang dianggap keramat (Koentjoroningrat, 1954: 103). Sedangkan dinamisme adalah suatu istilah dalam antropologi untuk menyebut sesuatu pengertian tentang suatu kepercayaan. Dimana kata dinamisme berasal dari bahasa Yunani dynamis atau dynaomos yang artinya kekuatan atau tenaga (Ahmadi, 1991: 35). Dinamis adalag keyakinan terhadap benda-benda tertentu yang memiliki kekuatan gaib, karena itu harus dihormati dan terkadang harus dilakukan ritual tertentu untuk menjaga tuah-nya (kekuatan yang ada dalam benda tersebut). keyakinan semacam inilah yang membentuk perilaku manusia pada kehidupan sehari-hari, baik dalam wujud etika maupun ekspresi berkesenian.

Melalui proses pewarisan dari generasi ke generasi selanjutnya, tradisi dapat mengalami perubahan-perubahan baik dalam skala besar maupun dalam skala kecil. Perubahan tersebutlah yang dikatakan sebagai invented tradition, dimana tradisi tidak hanya diwariskan secara pasif, tetapi juga direkontruksikan dengan maksud membentuk atau menanamkannya kembali kepada orang lain.

Dalam Islam banyak sekali tradisitradisi yang telah diturunkan dari generasi ke generasi. Misalkan dalam Perayaan Hari Besar Islam (PHBI) seperti hari raya idul fitri, idul adha (hari raya qurban), isra' mi'raj, maulid nabi, tahun baru Islam dan masih banyak lagi perayaan-perayaan lainnya. Diseluruh belahan negara manapun apabila merayakan $\mathrm{PHBI}$ memiliki tradisinya masing-masing dalam memeriahkan perayaan-perayaan tersebut. seperti di Indonesia yang mayoritas penduduknya pemeluk agama Islam banyak sekali cara untuk merayakan setiap perayaan yang ada. Kebiasaankebiasaan tersebutlah yang dilestarikan oleh para penerus dari suku merekan masing-masing.

\section{E. Pengertian Komunikasi}

Komunikasi merupakan proses penyampaian pesan dari komunikator atau pembawa pembawa pesan kepada komunikan atau penerima pesan dimana pesan tersebut di maknakan sama serta dalam penyampaian pesannya dapat menggunakan media atau alat bantu penyampaian pesan.

Komunikasi mengacu pada tinda- 
kan, oleh satu orang atau lebih, yang mengirim dan menerima pesan yang terdistorsi oleh gangguan (noise), terjadi dalam sutau konteks tertentu, mempunyai pengaruh tertentu dan ada kesempatan untuk melakukan umpan balik.

Dalam komunikasi terdapat empat tujuan (dalam Onong Uchjayana Effendy, 1999: 8) yaitu untuk perubahan sikap (attitude change), perubahan pendapat (oponion change), perubahan perilaku (behavior change), perubahan sosial (sosial change).

Mulyana menyebutkan terdapat empat fungsi komunikasi bagi manusia. Pertama komunikasi sosial dimana fungsi komunikasi sebagai kkomunikasi sosial setidaknya mengisyaratkan bahwa komunikasi itu penting untuk membangun konsep diri seseorang. Kedua komunikasi ekspresif yang berkaitan dengan komunikasi sosial yang dapat dilakukan baik sendirian ataupun dalam kelompok. Ketiga komunikasi ritual berkaitan dengan komunikasi ekspresif dimana pada komunikasi ritual ini respon manusia dalam menanggapi lambang-lambang yang tidak jarang bersifat ekstrem dan tidak masuk akal kebanyakan oarang. Keempat komunikasi instrumental yang memiliki tujuan menginformasikan, mengajar, mendorong, mengubah sikap dan keyakinan, mengubah perilaku, serta untuk menghibur. (Mulyana, 2002: 5-30)

\section{F. Pengertian Ritual dan Fungsi Ritual}

Manusia yang mengalami perubahan dari proses kehidupan sehariharisampang dengan ritual-ritual yang dilakukan dalam peringatan hal-hal yang dianggap sangat berarti, penting ataupun mempunyai nilai suci. Ritual yang dilakukan berbeda-beda bentuk dan prosesinya, hal ini mempertimbangkan ritual apa yang akan dilaksanakan. Kehidupan manusia sejak dalam kandungan, kelahiran, perkawinan sampai dengan kematian dipenuhi ritual-ritual.

Upacara adalah suatu tindakan atau serangkaian tindakan yang dilaksanakan menurut adat kebiasaan atau keagamaan yang menandai kesucian dan kekhitmatan suatu perbuatan (Shadily, 1984: 31). Menurut Koentjaraningrat, upacara atau ritus adalah aktivitas dan tindakan masnusia dalam melaksanakan kebaktiannya terhadap Tuhan, dewa-dewa, roh nenek moyang atau makhluk halus lain serta dalam usahanya untuk berkomunikasi dengan Tuhan (Koentjaraningrat, 1987; 81). Dengan demikian upacara atau ritus merupakan perilaku simbolis untuk mengkonsolidasikan atau memulihkan tata alam dan menempatkan manusia dan perbuatannya dalam tatanan tersebut. dalam ritus dipergunakan kata-kata, do'a dan gerak gerik tangan atau badan (Subagya, 1981: 116).

Ritus mempunyai ciri yang khas yaitu membangkitkan kembali situasi awal 
dengan memunculkan kembali dan karakteristik perasaan yang tepat serta mengalihkan perhatian dari beberapa aspek situasi dan memusatkannya pada aspek lainnya. Dalam upacara keagamaan tidak hanya dilakukan untuk sesuatu akan tetapi mengungkapkan suatu sikap.

Ritus berasal dari kebutuhan manusia secara primer, maka ritus merupakan kegiatan yang spontan dalam arti betapun peliknya ritus tersebut terjadi, tanpa harus disesuaikan dengan tujuan yang disadari, tanpa rancangan, pola ritus benar-benar alamiah. Ritus terjadi pada saat-saat kejadian terpenting seperti kelahiran, kematian, masa puber, sakit, perkawinan, perubahan status sosial dan lain sebagainya.

Fungsi ritus adalah untuk memberikan ketenangan dalam kecemasan, ragu dan bahaya yang akan dialami dengan cara mengantisipasi dan mengatasinya secara simbolis. Menurut Durkheim upacara atau ritus dapat mengukuhkan kembali kelompok lewat pemujaan. Dengan kata lain ritus merupakan sarana bagi kelompok atau individu secara periodic untuk mengukuhkan kembali dirinya dengan menggunakan ritus tertentu atau khusus (Durkheim, 1992: 443).

Ritus merupakan pengulangan sentimen secara tetap dan merupakan pengulangan sikap yang benar dan pasti. Ritus menanamkan sikap kesadaran diri yang tinggi, memperkuat masyarakat dan memperkuat komunitas moral masyarakat. Ritus yang diulang secara teratur atau berkesinambungan dan adanya keteraturan dalam ritus maka akan dapat menyalurkan emosi dengan simbol-simbol yang dipergunakan dalam ritus secara simbolik (Nottingham, 1993: 16).

Komunikasi ritual yang bersifat ekspresif menjadi instrument untuk menyampaikan perasaan-perasaan (emosi). Perasaan-perasaan tersebut terutama dikomunikasikan melalui pesanpesan nonverbal (Mulyana, 2002: 21-22). Simbol nonverbal ini dapat saja berupa sesaji biasanya menggunakan tumbuhan dari jenis bunga dan benda-benda yang dianggap suci serta memiliki filosofi didalamnya.

\section{G. Deskripsi Tradisi Burak di Kota Bengkulu}

Banyak sekali tradisi-tradisi yang telah dilestasrikan dan dijaga oleh masyarakat suku Bugis. Salah satu tradisi tersebut yakni tradisi Burak.Tradisi Burak merupakan tradisi yang dilakukan oleh suku Bugis yang merupakan salah satu suku dari empat suku yang ada di provinsi Sulawesi Selatan yakni suku Bugis, suku Makassar, suku Toraja, dan suku 
Mandar ${ }^{1}$.

Tradisi Burak dilaksanakan pada saat prosesi pernikahan, zaman dahulu suku Bugis menggunakan burak ini sebagai bentuk dari mas kawin pernikahan. Jumlah tingkatan pada burak tersebut juga melambangkan siapa yang memiliki perayaan tersebut. Pada zaman dahulu burak dengan 88 tingkat merupakan lambang keluarga raja yang meminang, 44 tingkatan kaum bangsawan dan 22 tingkatan masyarakat biasa.

Seiring dengan transmigrasi yang terjadi dan perbauran budaya maka tradisi burak ini di kota Bengkulu dilakukan juga pada perayaan Maulid Nabi Muhammad SAW, khatam Qur'an bagi pasangan yang hendak menikah dan syukuran keliharan bayi (Aqiqah) $)^{2}$.

Burak dibuat untuk diberikan atau disedekahkan kepada kerabat atau tetangga yang ada di sekeliling lingkungan tempat tinggal atau kepada jamaah masjid yang datang pada saat perayaan Maulid Nabi Muhammad SAW.

Burak terbuat dari susunan batang bambu $^{3}$ yang ditancapkan bertingkattingkat pada sebatang pisang. Batang bambu tersebut terdapat telur rebus, serta dihiasi dengan kertas berwarna-warni

1 Wawancara dengan bapak Daeng Parani, tokoh adat Suku Bugis di Bengkulu, 8 Mei 2017

2 Wawancara dengan Agus masyarakat suku Bugis di Bengkulu.

3 Pohon bambu yang di belah menjadi bagian kecil kecil sehingga bisa di tancapkan pada pohon pisang kemudian diujung belahan yang mempercantik tampilan burak. Selain itu terdapat pula hiasan bunga pada ujungujung batang bambu pada Burak.

Penyusunan batang bambu terdapat hitungan tingkatannya yakni untuk burak kecil berjumlah 12 tingkat batang bambu, burak dengan ukuran sedang berjumlah 22, 24 batang bambu, serta burak dengan ukuran besar berjumlah 44, 48 sampai dengan 88 tingkat batang bambu 4 .

Pada suku Bugis khatam Qur'an merupakan kewajiban yang harus dilakukan sebelum mereka melakukan ijab dan qabul. Dalam prosesi khatam Qur'an inilah Burak juga dibuat sebagai tanda bersyukur kepada Allah SWT5.

Suku Bugis juga membuat Burak pada saat peringatan Maulid Nabi Muhammad SAW, dimana pada perayaan ini banyak masyarakatnya yang membawa Burak dengan berbagai ukuran. Tidak ada kewajiban bagi masyarakat Bugis untuk membawa dan membuat Burak. Tetapi menurut Rifki selaku masyarakat suku Bugis yang bertempat tinggal di Bengkulu, "tradisi tersebut harus tetap lestarikan untuk menjaga agar kebiasaan yang sudah ada dari nenek moyang asli dari suku Bugis yang ada di Sulawesi

bambu tersebut dibuat tempat untuk mengantungkan sebutir telur, pada setiap belahan bambu di berika sebutir telur.

4 Wawancara dengan Bapak Ambok Upek, Tokoh masyarakat suku Bugis di

Bengkulu, 10 Mei 2017

5 Wawancara dengan Bapak Hamsanudin, tokoh masyarakat suku Bugis di Bengkulu 
Selatan"6.

Selain dari Burak, pada saat Maulid Nabi Muhammad SAW masyarakat suku Bugis juga membuat Sesok. Sesok adalah bentuk lain dari Burak, dimana Sesok tidak menggunakan batang pisang sebagai penyanggah untuk menancapkan batang bambu dan telur melainkan menggunakan ember, baskom atau tempat lain yang digunakan untuk meletakkan batang bambu dan telur. Batang bambu yang telah diletakkan telur dan juga sudah dihias oleh kertas warna-warni sebagai bentuk daunnya serta ditancapkan bunga sebagai penutup ujung batang bambu yang runcing agar tidak berbahaya yang terbuat dari buah pepaya atau busa tersebut ditancapkan kedalam baskom atau ember yang telah diisi dengan nasi ketan agar batang bambu tersebut berdiri (Hasil survey, 8 Maret 2017).

\section{G.1. Simbol-simbol dalam Burak}

Tradisi Burak mengunakan bebrapa simbol-simbol yaitu:

1. Batang pisang sebagai penyangga utama

2. Batang bambu sebagai ranting

3. Telur rebus (telur ayam atau telur bebek) sebagai buah

4. Kertas warna-warni sebagai daun

5. Buah pepaya atau gabus yang dibentuk sebagai bunga.

\section{G.2. Makna Simbol tradisi burak}

Tradisi Burak terdapat lima simbol yang memiliki maknanya masing-masing disetiap simbolnya. Tradisi Burak yang laksankan oleh masyarakat suku bugis merupakan sebuah bentuk rasa syukur kepada sang pencipta Allah SWT yang telah memberikan nikmat dan rahmatnya berupa keturunan kepada umatnya. Sesuai dengan pelaksanaan tradisi tersebut Burak dibuat pada saat memperingati kelahiran Nabi Muhammad SAW, Aqikah serta khataman AI-Qur'an bagi masyarakat suku Bugis yang akan menikah.

Burak merupakan sebuah susunan mulai dari batang pisang, yang ditusuk bambu, pada ujung bambu digantung telur dan dihias kertas warna-warni sebagai bentuk daun serta buah pepaya atau gabus yang dibentuk bunga yang berfungsi sebagai penutup ujung bambu yang runcing agar tidak berbahaya. Burak sendiri memiliki hitungan banyaknya telur yang di gantung yakni untuk burak kecil berjumlah 12 tingkat batang bambu, burak dengan ukuran sedang berjumlah 22, 24 batang bambu, serta burak dengan ukuran besar berjumlah 44, 48 sampai dengan 88 tingkat batang bambu.

Dahulu telur yang digunakan pada Burak yaitu telur rebus yang langsung ditancapkan pada ujung bambu. Namun pada perkembangannya sekarang telur

6 Wawancara dengan Rifki Aditya Novaldi, Masyarakat suku Bugis di Bengkulu 
rebus tersebut tidak lagi secara langsung ditusukkan karena telur yang secara langsung ditusukkan tidak dapat bertahan lama atau cepat basi. Sehingga agar menjaga telur rebus tetap dalam kondisi baik suku Bugis dengan menggantungkan telur yang telah diberi wadah seperti jaring atau wadah mineral gelas.

Pada perayaan Maulid Nabi Muhammad SAW Burak digantung pada langit-langit teras masjid yang nantinya akan dibagikan kepada para jamaah yang datang setelah rangkaian kegiatan Maulid Nabi Muhammad SAW dilaksanakan.

Burak berfungsi sebagai pencapaian rasa syukur kepada Allah SWT sebagai maha pencipta. Burak yang dilaksanakan pada saat perayaan kelahiran ini disimbolkan dengan dibagikannya telurtelur kepada masyarakat yang memperingati setiap peringatan lahirnya hamba Allah SWT termasuk pada peringatan Maulid Nabi Muhammad SAW.

Adapun nilai atau makna yang terdapat dalam tradisi Burak tersebut yakni mulai dari nilai religious, nilai adat serta nilai kemasyarakat.

Batang pisang dipilih sebagai penyangga Burak adalah sebuah pohon yang unik karena pohon pisang akan tetap tumbuh sebelum berbuah meskipun di tebas pohonnya, oleh karena itu hal ini di maksudkan bahwa seorang muslim harus mempunyai harapan yang tinggi untuk menegakkan agama meskipun banyak sekali halangan dan rintangan dalam mempertahankan agamanya yakni Islam.

Batang bambu sebagai ranting penggantung telur yang ditancapkan pada batang pisang. Dimana bambu digunakan karena pohon bambu adalah sebuah pohon yang selalu tegak lurus, hal tersebut dimaksudkan bahwa umat Islam harus mempunyai aqidah yang kuat dan lurus untuk menyembah Allah SWT ibarat seperti lurusnya pohon bambu serta dapat mecontoh sikap Rasulullah SAW yang mulia seperti pohon bambu tumbuh menjulang tinggi.

Telur digunakan sebagai salah satu simbol dalam burak karena telur merupakan sebuah wujud dari sebuah kelahiran. Telur sendiri memiliki filosofi tersendiri dimana telur memiliki tiga bagian yakni kulit, putih telur dan kuning telur. Ketiga bagian telur tersebut bermakna sebagai pertama kulit telur yakni wujud fisik manusia yang terlihat oleh panca indra manusia, kedua putih telur yakni jiwa manusia, serta ketiga kuning telur atau inti yang berada ditengah-tengah butir telur yakni bermakna sebagai hati manusia dimana dalam Al-Qur'an disebut dengan qolbu.

Kertas berwarna sebagai bentuk daun dan buah pepaya atau gabus yang di bentuk seperti bunga merupkan hiasan yang memperindah tampilan burak. Hiasan tersebut dimaksudkan bahwa dengan kelahiran Rasullulah SAW maka berbahagialah seluruh alam sesuai 
dengan tujuan beliau yaitu sebagai rahmat bagi seluruh alam.

Dari kelima komponen dalam Burak yang disusun menjadi satu kesatuan berbentuk pohon yang lengkap dengan batang, ranting, buah, bunga dan daun menggambarkan rasa syukur kepada Allah SWT yang maha pencipta serta maha segalanya.

\section{Kesimpulan}

Makna simbol yang terdapat dalam tradisi Burak diantaranya yakni makna atau nilai religious, nilai adat serta nilai kemasyarakat. Simbol yang ada pada Burak yakni batang pohon pisang, pohon bambu, telur, kertas berwarna dan buah pepaya atau gabus berbentuk bunga. Masyarakat suku Bugis dimanapun mereka tinggal untuk menjaga kebiasaan yang telah ada dan dijalankan oleh nenek moyang mereka maka tradisi Burak ini tetap dilaksanakan. Burak yang nantinya dibagikan kepada warga masyarakat yang berada dilingkungan atau jamaah masjid yang mengikuti peringatan yang dilaksanakan. Burak merupakan perwujudan dari rasa syukur kepada Allah SWT yang telah memberikan karunia berupa sebuah kelahiran.

\section{Daftar Pustaka}

Ahmadi, Abu, 1991, Perbandingan Agama, Jakarta: Rineka Cipta.

Aminuddin, 1997, Stilistika, Pengantar Memahami Bahasa dalam Karya Sastra, IKIP, Semarang Press.
Arikunto, Suharsimi, 2012, Prosedur Penelitian: Suatu Pendekatan Praktik, Jakarta: Rineka Cipta.

Kuncoroningrat, $\quad 1954, \quad$ Sejarah Kebudayaan Indonesia, Yogyakarta: Jambatan.

Margono S, 2009, Metode Penelitian Pendidikan, Jakarta: Rineka Cipta.

Moleong J. Lexy, 2009, Metodologi Penelitian Kualitatif, Bandung: Remaja Rosdakarya.

Mulyana, Deddy, 2001, Metodologi Penelitian Kualitatif, Bandung, Remaja Rosdakarya.

Nasution, 2008, Metode Research (Penelitian Ilmiah), Jakarta: Bumi Aksara.

Nasution, Suryabrata, 2003, Metode Penelitian Naturalistik Kualitatif, Bandung: Tarsito.

Pateda, Mansur, 2001, Sosiolinguistik, Bandung: Angkasa.

Rohedi, Rohidi Tjetjep, 1983, Simbol dan Simbolism (Suatu Pengantar Singkat dalam Wilayah Kesenian, Semarang: Institut Keguruan dan IImu Pendidikan.

Saifudin dan Arikunto, 2009, Metode Penelitian, Yogyakarta: Pustaka Pelajar.

Sobur, Alex, 2003, Semiotika Komunikasi, Bandung: Remaja Rosdakarya. ., 2014, Ensiklopedia Komunikasi P. $Z$, Bandung: Sembiosa Rekatama.

Sugiyono, 2009, Metode Penelitian Kuantitatif, Kualitatif dan $R \& D$, Bandung: Alfabeta.

Wiyoso Yudoseputro, 1991, Nafas Islam, Kebudayaan Indonesia, Jakarta: Departemen Pendidikan dan Kebudayaan.

Rini Fitria, 2005, Ritual Tabut Sebagai Media Komunikasi Masyarakat Kota Bengkulu (Pola Komunikasi Pelaksana Ritual Tabut di Kota Bengkulu, Bandung: Tesis Universitas Padjadjaran Bandung. 
